\title{
THE EFFECTIVENESS OF ROLE PLAY METHOD TOWARDSTUDENTS' MOTIVATION IN ENGLISH CONVERSATION
}

\author{
Samsibar \\ Universitas Islam Negeri Alauddin Makassar \\ Samsibaranti@gmail.com \\ Wahyuddin Naro \\ Universitas Islam Negeri Alauddin Makassar \\ wahyuddin@uin-alauddin-ac-id
}

\begin{abstract}
This study aims to find the effectiveness of role play method toward the students' motivation in English conversation for the first grade students at MTs As'adiyah No. 49 Bola Aserae - Belawa academic year 2016/2017. The method used in this study was quantitative research through pre-experimental method by using one shot case study pre-test and post-test design. Before the treatment, the reseracher did the pretest in one class. Moreover, the researcher taught English conversation by role play technique in the experimental class. The last, the researcher conducted the post-test to know whether a role play technique was effective for teaching English conversation in experimental class. As the quantitative method, the researcher analized the data by using the t-test (4.37) which was higher than t-table value (2.093). The result showed that there was significant difference on the students' speaking achievement taught by using role play. The students' mean score of the pre-test of the experiment class was 52.4. Then, in the post-test, the mean score of experiment class was 65 . Therefore, hypothesis $\mathrm{H}_{0}$ was rejected and $\mathrm{H}_{1}$ was accepted. It could be said that role play method was effective in teaching English conversation toward the students' motivation for the first grade of junior high school students.
\end{abstract}

Keyword: Role Play, Students' Motivation.

\section{A. INTRODUCTION}

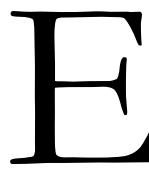

nglish became the most essential languages in the world. Almost people from many different countries around the world used it to communicate. The area of

English had always become a special interest. This indicated that learning English language was not only learning vocabulary and grammar, but also it tried to use or apply that knowledge into communication activities. This thing came from the importance of English in any scope of our lives.

Edge (1993:25) states that British trade, followed by colonial and imperial expansion, English spread around the world. Since then, the military and economic dominance of the United States of America had confirmed English as the international language of present historical period. As a consequence, English served for many people as a bridge into the worlds of higher education, science, international trade, politics, tourism or any other venture which interested them. At the same time, English served for many times many more people as a barrier between themselves and those some fields of interest. Many 
people in their own countries were not be able to become doctors, for example if they cannot learn English well.

In international relationship, English speaking ability is very important to be able to participate in the wider world of work. The speaking skill was measured in terms of the ability to carry out a conversation in the language. This reality made teachers and parents thought that speaking ability must be mastered by their students and children.

Based on the previous reasons, English teaching had focused on teaching the English language. The emphasis was not only on linguistic competence of the language learners but also on the development of their communicative ability. In order to develop learners' communicative ability, the teacher needed to create a scenario to teach the target language in a vibrant, active and interesting manner.

In Indonesia, learning English conversation was a difficult thing for the student because English was a foreign language. In this situation the students, even the teachers had a little chance to communicate in English except only when the students were in the classroom or in certain places where English was spoken. However, it cannot be denied that English language was still a critical problem for the Indonesian students. It caused serious problem in learning activity, the students did not reach good achievement in their study because there is no spirit or passion on it. Motivation was an impulse energy that caused or stimulated to person for act. This meant a person's act was according to motivation. A motivation was something that needed to do activities. In other word, without motivation someone or person did not do any kind of activities.

In learning speaking skill, the students often found some problems. The problem frequently found was that, their native language caused them difficult to use the foreign language. Other reason was the lack of motivation to practice the second language in daily conversation. The students were also too shy and afraid to take part in the conversation. Many factors caused the problem of the students' speaking skills, namely the students' interest, the material, and the media among others including the technique in teaching English. In order to minimalism these insufficiency, the teachers must have good strategy so that all these problems were handled and the goal of the teaching and learning were achieved. Many techniques were applied including role play method because many research findings said that, this technique was effective to be used in teaching speaking.

Role play was very important in teaching speaking because it gave students an opportunity to practice communicating in different social contexts and in different social roles. In addition, it also allowed students to be creative and to put themselves in another person's place for a while. According to Hatting (1993:165) based on his observation in the conversation class, the role play would seem to be the ideal activity in which students could use their English creatively and it aimed to stimulate a conversation situation in which 
students might found themselves and gave them an opportunity to practice and develop their communication skill.

Based on the previous background, the researcher interested to conducted research to motivate students in English conversation at the first grade in MTs No.49 Bola Aserae Belawa. All of these matters made serious problem either for the teachers or themselves to achieve the goal of learning. Besides, there were no various activities which offered different challenges for the students to practice. On the other side, many students did not speak in the classroom due to they were afraid of being wrong if they were asked to participate. Therefore, the first thing that must be overcome is the method that the teachers applied to handle the classroom well. Applying the good method helped the teacher to overcome the student's problems.

The researcher, therefore, offers a method which the researcher thought that may helped the students to speak English effectively. The researcher aimed to conduct this class to overcome or minimize the problems before by role play method.

\section{B. LITERATURE REVIEW}

\section{Previous Related Finding}

Thao (2013) conducted a research entitled "Applying role-play in increasing student' interest in learning speaking to grade 11 students at Lai Vung 2 high school". This research aimed to identify how students interest in learning speaking and to find out the effect of using role play in speaking classes. Also, it was intended to find out difficulties from using role play activities so that the researcher suggested some solutions to these difficulties. The role play was described as a technique which involved imagination to be someone else or to be ourselves in a specific situation for a while, improvising dialog and creating a real world in scenario. Role play activities encouraged students' thinking and creativity, helped students developed and practiced new language and behavioral skills in a relatively non- threatening setting, and created the motivation and involvement necessary for learning to occur. Role play was a powerful and effective teaching method for children and adult and was adapted to deliver any learning objectives from simple to complex concepts. It really lended well to practice communication skills, debated complex ethical issues or explore attitudes and beliefs. The success lied in the construction and delivery with careful facilitation.

Susanti (2007), conducted a research entitled "Using Role Play in Teaching Speaking at Islamic Junior High School Soebono Mantofani Jombang-Ciputat". In learning speaking skill, the students often found some problems. The problem frequently found that their native language caused them difficult touse the foreign language. The students were also too shy and afraid to take part in the conversation. Many factors caused the problem of the students speaking skills namely the students interest, the material, and the media among others including the technique in teaching English. Many techniques was applied including 
role play because many research findings said that this technique was effectively to use in teaching speaking.

Kusmana (2011), conducted a research entitled "The Influence of Role Play and Drills in Stimulating Students' Motivation for Learning English Conversation at the First Grade of SMP Darussalam Jakarta Selatan". The research explained that the students motivation improved through the use of role plays and made the students' to communicate well. The students were more confident and were not afraid of making mistakes when speaking. The students actively participated during the teaching and learning process.

As the conclusion, the researcher conducted this research with different subject, setting and design. There were three findings about role play method. The first finding was Thao focused on applying role play to increase students' interest in learning speaking. The second finding was Susanti focused on using role play method in teaching speaking. The third finding was Kusmana focused on the influence of role play method in stimulating students' motivation for learning English conversation. In this research, the researcher focused on the students' motivation to speak English conversation in front of the class through role play method. This research was taken a place at the first grade in MTs No. 49 Bola Aserae - Belawa.

\section{Pertinent Ideas}

Motivation is process of motivating; the condition of being motivating; a motivating force, stimulus, or influence; incentive; drive; something (such as a need or desire) that causes a person or student to act (Merriam- Webster, 1997. While according to Hermer (1993) motivation is internal drive that encourages people to pursue the goal. It means that motivation is an internal process that drives a person to pursue a goal.

Nurpahmi and Thamrin (Nurpahmi \& Thamrin, 2016) point out that motivation can empower people to do an action, either that encouragement from themselves (internal) or it from outside of themselves (external). Motivation has an important role in learning. Motivation affects student's learning process. Motivation increases a student's energy and activity level. Generally, more motivated students achieve higher levels of achievement.

Herzberg in Riley (2005) states that two factors that can cause people more motivated to do something, satisfaction and dissatisfaction. This theory explains two kinds of factors the motivation factors and hygiene factors. The motivating factors categorized as intrinsic motivation consist of achievement, recognition, work itself, responsibility, advancement, and possibility of growth. Hygiene factors which is categorized as extrinsic motivation consist of the subordinate, personal life and so forth. 


\section{RESEARCH METHOD}

This research was Pre- Experimental method with one group pre-test and post-test design. There were three designs in pre-experimental design; one shot case study, pre-test and post-test, and static group comparison. This research employed one group pre-test and post-test design. This design involved one group pre-test (O1), exposed to a treatment $(\mathrm{X})$, and post-test (O2). In this research, the subject of rearch was one group class. In the pretest and post-test design, this research aimed at knowing whether to know the effectiveness of Role play method toward the students' motivation to learn English conversation. Arikunto in As'ad (2014) recited that the nature of the research was pre-experimental using "pre-test and post-test on group design.

\section{FINDING AND DISCUSSION}

\section{Findings}

The findings of the research were based on the results of the data analysis. The data analysis was used to collect data. The students' motivation in English conversation consisted of pre-test and post-test. The pre-test was given to know the effectiveness of the students' motivation in English conversation before presenting role play method, and the post-test was given to know the effectiveness of the students' motivation in English conversation after giving the treatment.

\section{a. The Classification of Students' Pre-test and post-test Scores}

The analysis data, the researcher gave three components classification. They were Pronunciation, Grammar, Vocabulay, Comprehention, and Fluency. The students score was classified into some criteria as follow:

1) The students' Pre-Test Score

Table 1. The Distribution of Frequency and Percentage Score of The Pre-Test

\begin{tabular}{|l|l|l|l|l|}
\hline No & Classification & Score & Frequency & Percentage \\
\hline 1 & Very good & $85-100$ & 0 & $0 \%$ \\
2 & Good & $65-84$ & 5 & $25 \%$ \\
3 & Fair & $55-64$ & 2 & $10 \%$ \\
4 & Poor & $35-54$ & 12 & $60 \%$ \\
5 & Very Poor & $0-34$ & 1 & $5 \%$ \\
\hline Total & & 20 & $100 \%$ \\
\hline
\end{tabular}


Samsibar,St. Wahyuddin Naro., The Effectiveness of Role Play Method ...

Table 1 above shows the rate percentage score of the post-test from 20 students, there were $5(25 \%)$ students obtained good score but most of the students obtained poor.

Table 2. The Distribution of Frequency and Percentage Score of The Post-Test

\begin{tabular}{|l|l|l|l|l|}
\hline No & Classification & Score & Frequency & Percentage \\
\hline 1 & Very good & $85-100$ & 2 & $10 \%$ \\
2 & Good & $65-84$ & 7 & $35 \%$ \\
3 & Fair & $55-64$ & 7 & $35 \%$ \\
4 & Poor & $35-54$ & 4 & $20 \%$ \\
5 & Very Poor & $0-34$ & 0 & $0 \%$ \\
\hline \multicolumn{2}{|l|}{} & 20 & $100 \%$ \\
\hline
\end{tabular}

Table 2 above shows the rate percentage score of the post-test from 20 students. The students' score were increase, most of the students' in a good score and there were 7 (35\%) students obtained very good score.

2) The mean score and standard deviation Pre-test and the Post-Test

After calculating the result of the students score, the mean score and standard deviation can be presented in following table.

Table 3. Total Mean Score of Pre-Test and Post-Test

\begin{tabular}{|c|c|c|c|c|}
\hline \multirow{3}{*}{$\begin{array}{l}\text { Class } \\
\text { Experimental }\end{array}$} & \multicolumn{2}{|c|}{ Pre-test } & \multicolumn{2}{|c|}{ Post-test } \\
\hline & $\begin{array}{l}\text { Mean } \\
\text { Score }\end{array}$ & $\begin{array}{l}\text { Standard } \\
\text { Deviation }\end{array}$ & $\begin{array}{l}\text { Mean } \\
\text { Score }\end{array}$ & $\begin{array}{l}\text { Standard } \\
\text { Deviation }\end{array}$ \\
\hline & 52.4 & 18.30 & 65 & 66.61 \\
\hline
\end{tabular}

The table above shows that, the mean and the standard deviation of pre-test and post-test.

3) Test of Significance Testing

In order to know whether or not the mean score was statically different from two variables (pre-test and post-test) at the level of significant difference $(0,05)$ with degree of freedom $(\mathrm{df})=\mathrm{N}-1$, where $\mathrm{N}=$ the total of the students (20).

Table 4. The Following Table Show The Result of t-test Calculation

\begin{tabular}{|l|l|l|}
\hline Variable & t-test value & t-table value \\
\hline $\mathrm{X}_{2}-\mathrm{X}_{1}$ & 4.37 & 2.093 \\
\hline
\end{tabular}


Volume 4, Number 01, June 2018

The T-table above shows that the t-test value was higher than $\mathrm{t}$-table value. The $\mathrm{t}$ test got 4.37and t-table got 2.093. It meant that there was significant improvement after treatment so the students motivation in English conversation is affective as a source of material in teaching student's speaking.

\section{Discussion}

The result of data analysis showed that using role play method has managed to increase the students' motivation in English conversation it could be seen from the effectiveness of Role play method from the t-table above shows that the t-test value was higher than t-table value. The t-test got 4.37 and t-table got 2.093. It meant that there was significant improvement after treatment so the students motivation in English conversation was affective as a source of material in teaching students' speaking.

In general, the performance of the students improved by using role play method, most of them were in very good and good scores. The use of Role play method in teaching English conversation was effective. Some statements from the previous researcher supported this thesis, Abdillah (2014) said that role play method gives some experiences to the students' seeing that they involved in playing their role in English conversation directly and the students practiced speaking ability in front of their friends and grew their confidence while speaking in front of the class and this method practiced the students ability to express their idea and communicated each other. Susanti (2007) said that the role play also presents a real life situation and made the students can speak freely and confidently in front of their friend in a classroom and also can make lesson classroom activity enjoyable, active, secure. And the last, Kusmana (2011) said that role play method can made the students' were more confident and also not afraid of making mistakes when speaking. Related to some evidence before, the researcher believed that role play method improved students' motivation to speak English conversation.

In summary, the researcher assserted that the treatment by using role play method was surely beneficial to improve the students' motivation in English conversation at the first grade in MTs No. 49 Bola Aserae- Belawa. The method of the teaching was one of the factors that influence the result of the study.

\section{E. CONCLUSION}

Based on the result data analysis it is concluded that teaching English conversation by using role play method to the first grade students in MTs No. 49 Bola Aserae-Belawa 
Samsibar,St. Wahyuddin Naro., The Effectiveness of Role Play Method ...

was affective. It can be seen from the significant improvement of the students' motivation from the pre-test to the post-test. It meant that the research hypothesis $\left(\mathrm{H}_{2}\right)$ was accepted. The improvement can be seen from the statistical analysis that t-test (4.37) was higher than t-table value (2.093).

\section{REFERENCES}

Asik, N., \& others. (2016). The effectiveness of Using Visual Aids Integrated Communicative Language Teaching Method In Improving The Students'speaking Ability At The Second Grade Of Sman 1 Pinrang. ETERNAL (English, Teaching, Learning, and Research Journal), 2(2), 167-182.

Abnor, Abd. Rachman (1993). Psikologi Pendidikan. Yogyakarta: PT. Tiara Wacana Yogya.

Allen, Edward David \& M. Valette, Rebecca (1997). Classroom Techniques: Foreign Languages and English as a Second Language. New York: Hacourt Brace Javanovich.

Anthony, Edward M (1963). Approach Method and Technique English Language Teaching.

Arikunto, Suharsimi. (2013). Prosedur Penelitian: Suatu Pendekatan Praktik. Jakarta: PT. Rineka Cipta.

Bowers, Roger \& Brumfit, Chripstopher. (1991). Applied Linguistics and English Language Teaching. London and Basingstoke: Macmillan Publishers Limited.

Broughton, G. (1980). Teaching English as a Foreign Language. ed: $2^{\text {nd }}$. London: Routledge and Kogan Page Limited.

Budden, Joanna. (2006). Role Play. UK, London: BBC.

Byrne, Donn. (1986). Teaching Oral English: Longman Handbooks for English Teacher. Singapore: Longman Group.

Damopolii, Muljono. (2013). Pedoman Penulisan Karya Tulis Ilmiah: Makalah, Skripsi, Tesis,

Disertasi, dan Laporan Penelitian. Makassar: Alauddin Press.

Dick, W. and Carey, L.J.O. (2001). The Systematic Design of Instruction. Nairobi: Longman Publishers.

Djamarah, Syaiful Bahri.(2002). Psikologi Belajar. Jakarta: PT Rineka Cipta.

Edge, Julia. (1993). Essential of English Language Teaching. New York: Longman.

Gathumbi, A. W. and Musembe S. C. (2005). Principles and Techniques in Language Teaching. Nairobi: Jomo Kenya Institute Education.

Gay, L. R.(2006). Educational Research: Competence for Analysis and Application. ed: $2^{\text {nd }}$. Columbus: Charlest E., Merril Publishing Company. Abell \& Howel Company. 


\section{Volume 4, Number 01, June 2018}

Ladusse, Gillian Porter.(1995). Role Play: Resources Books for Teacher Series. New York: Oxford University Press.

Harmer, Jeremy. (2001). How to Teach English. Edinburg: Pearson Education Limited.

Harmer, Jeremy. (1983). The Practice of English Language Teaching: Longman Handbooks for Language Teaching. USA: Longman Inc.

Hong, S.(2005). Teaching English language Learners. New York: The guiltford Press.

J.S. Atherton. (2003). Learning and Teaching: Exercises: Role Play. United Kingdom.

John W. Santrock. (2004). Educational Psychology. ed: $5^{\text {th }}$.New York: McGraw-Hill.

Krish, Pamela. (2001). A Role Play Activity with Distance Learners in an English Language

Classroom. The Internet TESL Journal, Vol. VIII, No. 7, July 2001.

Kurnia. (2013). Penelitian Descriptive terhadap Siswa RSBI kelas XI Pasundan Bandung Tahun Ajaran 2012/2013.

Kusmana, Andi.(2011). The Influence of Role Play and Drills in Stimulating Students' Motivation for Learning English Conversation at the First Grade of SMP Darussalam Jakarta Selatan.

Kusnadi. (2002). The Application of Role Play as a Technique in Teaching Practical Conversation. Jakarta: UIN Syahid.

Larsen-Freeman, Diane. (2000). Techniques and Principles in Language Teaching: Teaching Techniques in English as a Second language. ed: $2^{\text {nd }}$. New York: Oxford University Press. Makmun, Abin Syamsuddin. (2003). Psikologi Pendidikan. Bandung: PT Remaja Rosdakarya. Ments, M. V. (1999). The Effective Use of Role Play, Practical Techniques for Improving Learning. Ed: $2^{\text {nd }}$. London: Kogan Page Limited.

Khairat, A. (2015). The Roles Of Academic Advisor To The Learning Motivation Of The Seventh Semester Students'of English Education At Alauddin State Islamic University Of Makassar. ETERNAL (English, teaching, Learning, and Research Journal), 1(2), 229245.

Nurpahmi, S., \& Thamrin, A. M. (2016). The Influence of Taking A Part Time Job Towards Students'learning Motivation At The Seventh Semester Students Of English Education Department Of Uin Alauddin Makassar. ETERNAL (English, Teaching, Learning, and Research Journal), 2(1), 63-81.

Patridge, Eric. (1947). A Guide To Good English. England: Penguin Books. 1947.

Rogers, S. and Evans, J. (2008) .Inside Role Play in Early Childhood Education: Researching Young Children's Perspective. U.S.A: Routledge. 
Samsibar,St. Wahyuddin Naro., The Effectiveness of Role Play Method ...

Slavin, Robert E. (1986). Educational psychology: Theory and Practice . ed: $8^{\text {th }}$. New York: Pearson.

Sudjana, Nana. (2010). Penilaian Hasil Proses Belajar Mengajar. Bandung: PT. Remaja Rosdakarya.

Sugiyono. Statistik Penelitian. Bandung: Alphabeta. 2004.

Susanti, Ayu Diyah Harni. Using Role Play in Teaching Speaking. 2007.

Tarigan, Henry Guntur. Berbicara Sebagai Suatu Keterampilan Berbahasa. Bandung: Penerbit Angkasa. 1986.

Thao, Le Dinh Mai. Applying Role Play in Increasing Student' Interest in Learning Speaking. 2013. 